A RCHIWA, BIBLIOTEKI

I MUZEA KOŚCIELNE 113 (2020)

https://doi.org/10.31743/abmk.10010

KS. JAN PIETRZYKOWSKI SDB* - WARSZAWA

\title{
ZAKONY I ZGROMADZENIA MESKIE W XX WIEKU W (ARCHI)DIECEZJI ŁÓDZKIEJ
}

\begin{abstract}
Streszczenie
Na terytorium powstałej w 1920 roku diecezji łódzkiej podejmowały pracę zarówno nowe zgromadzenia zakonne, jak i zakony o starej metryce powstania. Pewną nowość stanowią zakony laickie działające okresowo: bracia doloryści, albertyni, Bracia Serca Jezusowego oraz posługujący ciągle: bonifratrzy i bracia szkolni. Z zakonów kleryckich i zgromadzeń zakonnych działających w czasach staropolskich jako pierwsi w 1919 roku przybyli do Pabianic Misjonarze św. Wincentego à Paulo. Po II wojnie światowej osiedlili się karmelici trzewiczkowi w Łodzi i filipini w Tomaszowie Mazowieckim. W okresie międzywojennym salezjanie zorganizowali trzy placówki: szkolno-wychowawczą w Łodzi, duszpasterską w Łodzi i opiekuńczą w Lutomiersku. Pozostałe zgromadzenia zakonne mają po jednej parafii w Łodzi i na terenie archidiecezji: oblaci (Grotniki), pasjoniści, klaretyni, sercanie (Bełchatów) i pallotyni. Jako ostatni w 2004 roku w trzypiętrowej kamienicy w Łodzi zamieszkali dominikanie. Duszpasterze zakonni swoją działalnością obejmują różne środowiska społeczne i usiłują realizować swoje posłannictwo w Kościele lokalnym.
\end{abstract}

Słowa kluczowe: archidiecezja łódzka; zgromadzenia zakonne; duszpasterstwo; działalność szkolno-wychowawcza

Już pod koniec XIX wieku, jak i przez całe następne stulecie na terytorium powstałej w 1920 roku diecezji łódzkiej podejmowały pracę nowe zgromadzenia zakonne, jak i zakony o starej metryce powstania. W niniejszym artykule poszcze-

* Ks. Jan Pietrzykowski SDB - prof. historii; Instytut Historii, Uniwersytet Kardynała Stefana Wyszyńskiegow Warszawie; e-mail: jan_pie@poczta.onet.pl

https://orcid.org/0000-0001-5414-3902 
gólne zakony i zgromadzenia zakonne zostały zaprezentowane w układzie chronologicznym. Najpierw scharakteryzowano niektóre zakony laickie, a następnie zakony kleryckie. O kolejności decydowało powstanie pierwszej wspólnoty danej rodziny zakonnej. Biskupi diecezjalni byli bardziej zainteresowani sprowadzaniem nowych zgromadzeń zakonnych, odznaczających się wszechstronną działalnością w Kościele: duszpasterską, szkolną, wychowawczą, dobroczynną, charytatywną itp.

\section{Zgromadzenie Synów Matki Boskiej Bolesnej (Bracia Doloryści)}

Łódź. Bracia Doloryści to zgromadzenie męskie, bezhabitowe, założone w Nowym Mieście nad Pilicą w 1893 roku przez bł. o. Honorata Koźmińskiego. Bracia Doloryści, początkowo jako wędrowni rzemieślnicy, zajmowali się nauczaniem prawd katechizmowych i krzewieniem tercjarstwa franciszkańskiego, a w późniejszym okresie prowadzili szkoły zawodowe, internaty dla chłopców i czytelnie ${ }^{1}$.

Doloryści do Łodzi przybyli w 1896 roku i osiedlili się we wschodniej części dzielnicy Bałuty, na terenie parafii Wniebowzięcia NMP. Po uzyskaniu zgody władz carskich na placu między ulicami Spacerową i Dworską zbudowali dom zakonny, warsztaty, internat dla chłopców z okolic miasta i w roku 1900 rozpoczęli działalność szkolno-wychowawczą wśród młodzieży męskiej. W warsztatach uczyli młodzież rzemiosła: szewstwa, krawiectwa, piekarnictwa, ślusarstwa, kowalstwa, które w przyszłości miało jej zapewnić godziwe i uczciwe życie. Następnie w latach 1906-1907 zbudowali według projektu Kazimierza PomianSokołowskiego mały kościół rektoralny pw. Dobrego Pasterza, nawiązujący do stylu zakopiańskiego ${ }^{2}$. Po odzyskaniu przez Polskę niepodległości w 1918 roku Bracia Doloryści w Łodzi działali pod szyldem Towarzystwa Wychowawczo-Oświatowego „Przyszłość”. Pewną nowością i wyrazem postępu było w 1929 roku zbudowanie przez dolorystów kina przy ul. Młynarskiej, którego celem było propagowanie dobrych filmów. Niestety, z powodu powierzenia kierownictwa ludziom nieodpowiedzialnym cel nie został osiągnięty i po roku kino zamknięto ${ }^{3}$.

${ }^{1}$ W 1883 bł. o. H. Koźmiński założył pierwsze męskie zgromadzenie bezhabitowe, Braci Sług Maryi Niepokalanej. W 1893 podzieliło się ono na dwa odłamy: Braci Sług Maryi Niepokalanej, poświęcające się opiece nad młodzieżą wiejską, i dolorystów, którzy 6 V 1934 zostali zatwierdzeni przez Stolicę Apostolską. Z powodu braku powołań i zmniejszającej się liczby członków zgromadzenia dekretem z 2 III 2016 Bracia Doloryści zostali połączeni z zakonem Braci Mniejszych Prowincji św. Franciszka z Asyżu z siedzibą w Poznaniu. Por. M. Mazurek, M. Wójcik, Honorackie zgromadzenia bezhabitowe w latach 1874-1914 w Królestwie Polskim i Cesarstwie Rosyjskim. Materiaty do geografii historycznej ruchu zakonnego, w: Materiaty do zgromadzeń zakonnych na ziemiach polskich w XIX i na poczatku XX wieku, red. H. Dylągowa, Lublin 1976, s. 270-271; J. Duchniewski, Doloryści, synowie MB Bolesnej, w: Encyklopedia katolicka, t. 4, red. R. Łukaszyk, Lublin 1985, kol. 46; www.dolorysci.opoka.org.pl/index.html (dostęp: 19.07.2017).

${ }^{2}$ Archiwum Archidiecezji Łódzkiej (dalej: AAŁ), sygn. 45, t. Doloryści, Komitet Budowy Kościoła do arcybiskupa warszawskiego A. Chościak Popiela, Łódź 18 VI 1907.

${ }^{3}$ AAŁ, sygn. 48, t. Doloryści, Kierownik Zakładu do bp. W. Jasińskiego, Łódź 19 XII 1935. 
W dniu 1 lutego 1949 roku władze komunistyczne, powołując się na instrukcję Ministerstwa Oświaty z 4 maja 1948 roku, zlikwidowały szkołę zawodową, usunęły braci zakonnych, a przejęty majątek przeznaczyły na własne cele. Przy kościele Dobrego Pasterza 5 sierpnia 1951 roku biskup diecezjalny erygował parafię.

Łódź. Fabrykant Karol Szreibler przekazał kurii biskupiej budynek obok katedry przy ul. Piotrkowskiej 263, w którym Bracia Doloryści od stycznia 1930 roku do 12 marca 1940 roku prowadzili księgarnię katolicką. W lutym 1945 roku reaktywowali przedwojenną działalność przy ul. Piotrkowskiej w Łodzi. Na prośbę bp. Michała Klepacza od maja 1947 roku zamieszkali w budynku Księgarni „Przyszłość”. W dniu 14 grudnia 1948 roku funkcjonariusze łódzkiego UB przybyli do domów dolorystów w Łodzi - przy ul. Dworskiej nr 14 i ul. Piotrkowskiej nr 263 - i ogłosili zakonnikom decyzję władz państwowych zawieszającą działalność Zgromadzenia. Doloryści przyjęli propozycję przekazania swojej własności (kościoła, domu klasztornego, ogrodu i budynku gospodarczego) diecezji łódzkiej. Zakonnicy zostali zatrudnieni jako pracownicy fizyczni w Wyższym Seminarium Duchownym i w Kurii Biskupiej w Łodzi. Budynek przy ul. Piotrkowskiej nr 263 przejęły władze państwowe dla Stowarzyszenia PAX, które uruchomiło własną księgarnię 5 .

\section{Zakon Szpitalny św. Jana Bożego (bonifratrzy)}

Łódź. Bonifratrzy to zakon nieklerycki założony w Grenadzie w 1540 roku przez św. Jana Bożego. Członkowie tego zakonu składają dodatkowy ślub - służenia chorym. Do Rzeczypospolitej bonifratrzy przybyli w 1609 roku i założyli pierwszy klasztor oraz szpital dla chorych w Krakowie. Po kasatach klasztorów w okresie zaborów dopiero w wolnej Polsce w 1922 roku reaktywowali swoją prowincję zakonną składającą się początkowo z ośmiu konwentów ${ }^{6}$.

Początki bonifratrów w Łodzi sięgają roku 1924, kiedy to prowincjał br. Jacek Misiak kupił dom przy ul. Krótkiej dla braci, którzy zbierali ofiary na budowę przyszłego szpitala i klasztoru. Magistrat Miasta Łodzi odmówił bonifratrom przekazania sąsiedniej parceli pod budowę szpitala. Władze zakonne znalazły inną lokalizację i 8 sierpnia 1925 roku przy ul. Kościuszki 4 kupiły parterowy obszerny dom mieszkalny, budynek gospodarczy, ponad 2 ha parku, 1,5 ha ogrodu, sprzedając nieruchomość przy ul. Krótkiej. Stolica Apostolska pismem z 22 wrze-

${ }^{4}$ Dz. Urz. Min. Ośw. z 1948 r., nr 5, poz. 86; Archiwum Konferencji Wyższych Przełożonych Zakonów Męskich w Warszawie (dalej: KWPZ), t. Doloryści, br. J. Szczypiorski do Ud/sW, Warszawa 21 XII 1956, www.niedziela.pl/artykul/16247/nd/zdjecia_(dostęp: 19.07.2017).

${ }^{5}$ AAŁ, sygn. 46, t. Doloryści, , Br. J. Białomiejski do Kurii Biskupiej w Łodzi, Łódź 13 IV 1926, N. 112, sygn. 50, t. Doloryści, Br. J. Szczypiorski do Kurii Biskupiej, Radzymin 29 VI 1949; Bp M. Klepacz do Ministerstwa Administracji Publicznej w Warszawie, Łódź 13 II 1949, 191/49; A. Skopińska, Księgarnia w cieniu katedry, www.niedziela.pl/artykul/54429/nd/Ksiegarnia-w-cieniu-katedry (dostęp: 19.07.2017).

${ }^{6}$ Por. B. Łoziński, Leksykon zakonów w Polsce. Informator o życiu konsekrowanym, Warszawa 1998, s. 33-34; H. Gapski, Bonifratrzy w Europie Środkowo-Wschodniej do końca XVIII wieku. Rozwój sieci konwentów i szpitali, w: Bracia, czyńcie dobro. 400 lat Zakonu Bonifratrów w Polsce 1609-2009, red. M. Surdacki, Kraków 2009, s. 51-52. 
śnia 1925 roku nadała tej placówce status konwentu, a bp W. Tymieniecki dekretem z 3 listopada 1925 roku zezwolił na otwarcie domu zakonnego i publicznej kaplicy. W dniu 15 grudnia 1925 roku biskup diecezjalny poświęcił kaplicę w zaadaptowanym na ten cel budynku ${ }^{7}$ W latach 1928-1930 bonifratrzy zbudowali szpital i odpowiednio go wyposażyli. Z powodu wybuchu II wojny światowej nie zrealizowali planów budowy kościoła. W 1939 roku Niemcy przejęli cały obiekt na potrzeby wojska, a zakonników eksmitowali. Tylko w jednym pomieszczeniu pozostał przeor, a pozostali bonifratrzy zamieszkali w wynajętych kwaterach prywatnych. Po zakończeniu działań wojennych zarząd miejski odmówił bonifratrom zwrotu majątku i zakazał pracy w szpitalu. Bracia zamieszkali tymczasowo w zdewastowanym ,starym domku”. W 1945 roku do łódzkiej wspólnoty dołączyli bonifratrzy wysiedleni z Wilna. Przywieźli ze sobą skrzynie z suszonymi ziołami i receptury przyrządzania lekarstw, co dało początek działalności apteki i poradni ziołolecznictwa dla chorych.

Mimo podejmowanych prób władze komunistyczne odmawiały zwrotu bezprawnie zagarniętej własności. Od roku 1972 bonifratrzy podjęli starania o uzyskanie pozwolenia na budowę nowego obiektu przy ul. Kosynierów Gdyńskich 61a w Łodzi-Chojny. Dopiero w 1978 roku uzyskali zgodę na wzniesienie domu mieszkalnego. W dniu 8 grudnia 1980 roku biskup łódzki Józef Rozwadowski poświęcił nowy klasztor i kaplicę. W 1988 roku budynek klasztorny został podwyższony o trzecie piętro ${ }^{8}$. Z dniem 1 stycznia 2000 roku Szpital św. Jana Bożego w Łodzi powrócił do Zakonu Bonifratrów. Liczy 126 łóżek na czterech oddziałach. Ponadto działa przy nim ponad 20 poradni specjalistycznych świadczących usługi w ramach umowy z Narodowym Funduszem Zdrowia lub odpłatnie?.

\section{Zgromadzenie Braci Albertynów Trzeciego Zakonu Regularnego św. Franciszka Serafickiego Posługującego Ubogim (albertyni)}

Łódź. Bracia albertyni byli jedynym zgromadzeniem zakonnym pracującym w diecezji łódzkiej, które było założone na ziemiach polskich. W dniu 25 sierpnia 1888 roku Adam Chmielowski (1845-1916), jako brat Albert, na ręce biskupa krakowskiego Albina Dunajewskiego złożył śluby tercjarskie i tę datę uznaje się za początek braci albertynów. Adam Chmielowski zakładał dla ubogich i bezdomnych ogrzewalnie, przytułki, domy noclegowe, a także organizował dla nich pracę zarobkową i warsztaty rękodzielnicze ${ }^{10}$.

${ }^{7}$ AAŁ, sygn. 39, t. Bonifratrzy Łódź, O. Jacek Misiak do bp. W. Tymienieckiego, Kraków 26 II 1923, s. 1-3 (rękopis), 24 X 1924, Kraków, s. 1 (rękopis); M.M. Łobozek, Bonifratrzy w Łodzi 19251995, Łódź 1995, s. 21-24.

${ }^{8}$ Por. H. Łań-Mirowska, Bonifratrzy w Polsce (1609-1983), Rzym 1984, s. 107-108; Łobozek, Bonifratrzy w Łodzi, s. 25-31.

${ }^{9}$ Szpital Zakonu Bonifratrów św. Jana Bożego w Łodzi, https://bonifratrzy.pl/szpital-lodz/o-nas/historia-zakonu-bonifratrow-sw-jana-bozego/ (dostęp: 04.07.2017).

${ }^{10}$ Por. C. Strzeszewski, Kościół katolicki w Polsce wobec zagadnień spoleczno-gospodarczych (966-1918), w: Księga Tysiaclecia Katolicyzmu w Polsce, t. 3, red. M. Rechowicz, Lublin 1969, s. 397-399; J. Pietrzykowski, Zakony i zgromadzenia zakonne męskie na ziemiach polskich na przetomie XIX i XX wieku. Z uwzględnieniem diecezji janowskiej, czyli podlaskiej, „Roczniki Historii Kościoła", 4 (59) (2012) s. 88. 
Do diecezji łódzkiej albertyni przybyli w listopadzie 1938 roku na zaproszenie dyrektora Diecezjalnego Instytutu Akcji Katolickiej, ks. Stanisława Nowickiego, który 2 września 1938 roku wysłał do Zgromadzenia Albertynów w Krakowie prośbę o przyjazd zakonników do Łodzi ${ }^{11}$. Powodem skierowania zaproszenia był m.in. zakaz żebractwa w Łodzi z października 1937 roku i reorganizacja istniejących w mieście domów noclegowych. Wydział Opieki Społecznej w Łodzi w 1937 roku kupił posesję przy ul. Kątnej, która po adaptacji została oddana Komitetowi Walki z Zawodowym Żebractwem na dom noclegowy, z planem przekazania go na działalność opiekuńczą albertynom. $Z$ nieustalonych powodów Łódzkie Towarzystwo Przeciwżebracze 1 kwietnia 1938 roku przekazało braciom albertynom istniejący już Dom Noclegowy dla mężczyzn przy ul. Cmentarnej $10 \mathrm{w}$ Łodzi. Zgodnie z zawartą tymczasową umową Towarzystwo na potrzeby noclegowni miało asygnować $7500 \mathrm{zł}$ rocznie, wypłacanych w miesięcznych ratach, opłacać dzierżawę domu, remonty, urządzić kuchnię, jadalnię, łazienkę i świetlicę. Trzech braci zakonnych otrzymywało też opłaty pobierane od pensjonariuszy i za uzyskane w ten sposób pieniądze prowadziło placówkę i opłacało służbę pomocniczą ${ }^{12}$. Miejski Dom Noclegowy dla mężczyzn posiadał 200 miejsc. Od pensjonariuszy pobierano opłatę w wysokości 5 groszy. Nie przyjmowano do noclegowni osób chorych na choroby zakaźne, w stanie nietrzeźwym, usunięte z innych noclegowni oraz żebraków i włóczęgów. Albertyni mieli zamiar na stałe zatrzymać się w Łodzi i w tym celu podjęli stosowną korespondencję z Kurią Metropolitalną w Krakowie i Kurią Biskupią w Łodzi. Ich owocna praca w Domu Noclegowym przetrwała tylko do roku $1941^{13}$.

\section{Zgromadzenie Księży Misjonarzy Świętego Wincentego à Paulo (misjonarze)}

Pabianice. Zgromadzenie Księży Misjonarzy zostało założone w Paryżu w 1625 roku. W listopadzie 1651 roku przybyli do Warszawy na zaproszenie królowej Marii Ludwiki. W 1685 roku powstała Polska Prowincja Księży Misjonarzy, a w latach 1794-1842 działała Litewska Prowincja na ziemiach zabranych. Po kasacie domów zakonnych w 1864 roku w Królestwie Polskim już 28 marca 1865 roku utworzono nową prowincję polską pod nazwą Krakowska Prowincja Księży Misjonarzy ${ }^{14}$.

${ }^{11}$ AAŁ, sygn. 31, t. Albertyni, Brat starszy Zgromadzenia Albertynów do Diecezjalnego Instytutu Akcji Katolickiej w Łodzi, Kraków 31 I 1938.

${ }^{12}$ AAŁ, sygn. 31, t. Albertyni, Brat Starszy do Kurii Biskupiej w Łodzi, Kraków 15 XI 1936; P. Zwoliński, Działalność społeczno-dobroczynna Kościoła łódzkiego w okresie międzywojennym (studium historyczne), Łódź 2006, s. 246-247.

${ }^{13}$ Tamże, s. 248; Archiwum Wyższych Przełożonych Zakonnych w Warszawie (dalej: AWPZ), t. Albertyni, B. Mróz, Materiały do historii Kościoła w Polsce w latach 1939-1945 dotyczace Zgromadzenia Braci Albertynów, Kraków 1963, s. 9 (mps).

${ }^{14}$ Por. T. Salwa, Litewska Prowincja Księży Misjonarzy (1794-1842), „Nasza Przeszłość” (dalej: NP), 56 (1981) s. 147-148, 159; S. Janaczek, Powstanie i organizacja Krakowskiej Prowincji Księży Misjonarzy (1865-1914), NP, 86 (1996) s. 361, 366. 
Biskup diecezji kujawsko-kaliskiej S.K. Zdzitowiecki w styczniu 1919 roku zaproponował księżom misjonarzom objęcie nowej parafii w Pabianicach. Była to forma podziękowania biskupa za ich długoletnią posługę (1719-1864) w Wyższym Seminarium Duchownym we Włocławku. Parafia pw. NMP Różańcowej w Pabianicach posiadała duży neogotycki kościół w kształcie krzyża zbudowany w latach 1898-1903 pod kierunkiem Piotra Bukalskiego według projektu Tadeusza Markiewicza. Budynek sakralny został poświęcony 20 grudnia 1903 roku, a 20 grudnia 1906 roku biskup erygował drugą parafię w Pabianicach ${ }^{15}$.

Oficjalne przejęcie parafii pw. NMP Różańcowej w Pabianicach przez Księży Misjonarzy odbyło się 5 sierpnia 1919 roku, ale dopiero 25 lutego 1920 roku stała się ich własnością. Po zakończeniu formalności urzędowych nowi duszpasterze przystąpili do koniecznych remontów i prac wykończeniowych wystroju świątyni, kupna organów firmy „Krakowski” z Piotrkowa Trybunalskiego oraz budowy dwupiętrowej plebanii. Wkrótce obok domu zakonnego misjonarze wznieśli zabudowania gospodarcze, urządzili ogród i sad. Ze względu na dużą liczbę wiernych, granice parafii trzykrotnie ulegały zmianom w roku 1922, 1933 i 1981. Zmiany dokonane w okresie międzywojennym nie zmniejszyły jednak odległości z niektórych wiosek do kościoła. Dlatego w latach 1930-1933 w Dąbrowie zbudowano małą kaplicę o wymiarach $21 \times 10 \mathrm{~m}$, którą 6 listopada 1933 roku poświęcił bp Kazimierz Tomczak, sufragan diecezji łódzkiej ${ }^{16}$.

Parafia misjonarzy w Pabianicach mogła poszczycić się licznymi organizacjami nie tylko o charakterze religijnym, ale i społecznym. Szczególnie prężnie działały: Propaganda Prasy Katolickiej pw. św. Pawła i Katolickie Towarzystwo Dobroczynności, a od 1992 roku katolickie Liceum Ogólnokształcące im. św. Wincentego à Paulo. Celem pierwszej organizacji było propagowanie gazet katolickich, broszur i książek, głównie poprzez pozyskiwanie stałych prenumeratorów. Katolickie Stowarzyszenie Dobroczynności, w skład zarządu którego wchodził każdorazowy proboszcz, prowadziło sierociniec dla 60 dzieci, żłobek dla 20 podrzutków i ochronkę dla 150 biednych dzieci. W budynku, który był własnością stowarzyszenia, działała również szwalnia i hafciarnia. Ewenementem w skali diecezji łódzkiej była liczba 1500 członków Stowarzyszenia Żywego Różańca i 240 osób skupionych w Apostolstwie Modlitwy ${ }^{17}$.

\section{Towarzystwo św. Franciszka Salezego (salezjanie)}

Łódź. Dom pw. św. Barbary przy ul. Wodnej. Zakon salezjanów został założony w 1859 roku w Turynie przez św. Jana Bosko jako zgromadzenie ze szczególnym charyzmatem do pracy dydaktyczno-wychowawczej i apostolskiej wśród młodzieży męskiej. Pierwsza fundacja w Polsce w 1892 roku w Miejscu

${ }^{15}$ Schematyzm diecezji kujawsko-kaliskiej 1920, Włocławek 1920, s. 129.

${ }^{16}$ Por. W. Umiński, Polska Prowincja Zgromadzenia Księży Misjonarzy w latach 1918-1939, Kraków 2009, s. 71-72.

${ }^{17}$ AAŁ, sygn. 72, t. Misjonarze Pabianice, Historia kościoła i parafii w Pabianicach, s. 1-8 (mps); B. Markowski, Kościót i Parafia Najświętszej Maryi Panny w Pabianicach 1898-1998, Pabianice 1998, s. 25-27; Umiński, Polska Prowincja Zgromadzenia Księży Misjonarzy, s. 219-220. 
Piastowym nie powiodła się, dlatego salezjanie polscy za swój dom macierzysty uważają Oświęcim, do którego przybyli w roku $1898^{18}$.

$\mathrm{Z}$ inicjatywy bp. W. Tymienieckiego i prezesa Towarzystwa Rzemieślniczego „Resursa” Władysława Wagnera w sierpniu 1922 roku Towarzystwo Salezjańskie podjęło pracę w Łodzi w Szkole Rzemiosł przy Wodnej 34. W dniu 15 maja 1924 roku aktem darowizny salezjanie otrzymali Szkołę Rzemiosł na własność, a Ministerstwo Wyznań Religijnych i Oświecenia Publicznego nadało jej prawa szkoły państwowej. W 1925 wybudowano dodatkowy budynek szkolny z internatem i halami fabrycznymi. W maju 1926 roku w nowej dużej kaplicy odbył się Salezjański Kongres Misyjny. Patronem domu zakonnego jest św. Barbara (13 stycznia 1931). W 1936 roku Szkoła Rzemiosł przekształciła się w 4-letnie Gimnazjum Mechaniczne i 3-letnią Szkołę Mechaniczną ${ }^{19}$.

Podczas okupacji niemieckiej szkoła mimo dużych trudności działała do kwietnia 1940 roku. Wtedy władze usunęły zarząd salezjański, a cały obiekt wykorzystano na zakłady szkoleniowe dla ministerstwa lotnictwa Rzeszy. Po wycofaniu się Niemców już 21 stycznia 1945 roku salezjanie przejęli cały obiekt i wkrótce rozpoczęli rok szkolny. W związku z reformą szkolnictwa w PRL w roku 1950 powołano: Liceum Mechaniczne, Technikum Mechaniczne i Zasadniczą Szkołę Mechaniczną. W ostatnim etapie, od 1956 roku do likwidacji w 1962 roku, działała tylko 3-letnia Zasadnicza Szkoła Metalowo-Odlewnicza ${ }^{20}$.

W dniu 2 lipca 1991 roku salezjanie odzyskali swoją własność przy ul. Wodnej. W części budynku otwarto w tym samym roku koedukacyjne Liceum Ogólnokształcące im. ks. Jana Bosko. W latach 1994-1997 lokale wykorzystywano po południu na prowadzenie 2-letniej Policealnej Szkoły Administracji i Biznesu oraz Zaocznego Liceum Ogólnokształcącego dla pracujących. Inicjatywy te okazały się nietrwałe, dlatego też w 1996 roku otwarto 3-letnią Salezjańską Wyższą Szkołę Ekonomii i Zarządzania. W latach 1999-2017 salezjanie prowadzili także Gimnazjum im. ks. Jana Bosko w Łodzi ${ }^{21}$.

Z salezjańskiej szkolnej kaplicy korzystali także okoliczni mieszkańcy. Po przejęciu szkoły przez państwo głównym ośrodkiem działalności salezjanów był kościół. Od 1960 istniał przy kaplicy samodzielny ośrodek duszpasterski. Przełożony domu zakonnego był wikariuszem parafii pw. Podwyższenia Krzyża Świętego i dopiero 24 maja 1978 bp J. Rozwadowski utworzył parafię pw. Matki

${ }^{18}$ Por. K. Szczerba, Kontakty Polaków z księdzem Janem Bosko, „Seminare. Poszukiwania-naukowo pastoralne” (dalej: „Seminare”), 9 (1987-1988) s. 124-127; S. Zimniak, Salesiani nella Mitteleuropa. Preistoria e storia della provincia Austro-Ungarica della Societá di S. Francesco di Sales (1868 ca.-1919), Roma 1997, s. 70-71.

${ }^{19}$ Por. Archiwum Salezjańskie Inspektorii Warszawskiej (dalej: ASIW), t. Łódź-Wodna, Decretum canonicae erectionis Domus, 31 I 1931 N. 201; Sprawozdanie do Domu Generalnego w Turynie, Łódź 29 III 1938; 25-lecie działalności salezjańskiej w Polsce, Mikołów 1923, s. 23; J. Pietrzykowski, Szkoła salezjańska w Łodzi 1922-1992, „Seminare”, 10 (1994) s. 230-231.

${ }^{20}$ Por. W. Żurek, Salezjańskie szkolnictwo ponadpodstawowe w Polsce 1900-1963. Ustrój i organizacja, Lublin 1996, s. 279-282, 421.

${ }^{21}$ J. Pietrzykowski, Wkład salezjanów w życie Kościoła (Archi)diecezji Łódzkiej 1922-1998, „Łódzkie Studia Teologiczne”, 7 (1998) s. 310-311. 
Bożej Wspomożycielki Wiernych. Na jej terenie mieszka ok. 6000 wiernych ${ }^{22}$.

We wrześniu 1992 w części gmachu głównego budynku przy ul. Wodnej umieszczono Studentat Filozoficzny przeniesiony z Kutna-Woźniakowa. Studentat Filozoficzny tworzył odrębną wspólnotę zakonną pw. św. Józefa. Na pierwszych dwóch kursach kształcili się alumni z dwóch inspektorii: pilskiej i warszawskiej. Staraniem ks. insp. Zbigniewa Malinowskiego dobudowano nową część do budynku głównego, wycofano studentów teologii z Lądu i utworzono dla nich w Łodzi 15 maja 1996 r. nowy dom zakonny pw. św. Franciszka Salezego. Z kolei klerycy pilscy zostali przeniesieni do Lądu. Od 1996 w Wyższym Seminarium Duchownym Towarzystwa Salezjańskiego zdobywali wiedzę filozoficzną i teologiczną także pasjoniści, którzy każdego dnia dojeżdżali na zajęcia z Łodzi-Teofilowa ${ }^{23}$.

Lódź. Parafia św. Teresy i św. Jana Bosko. Salezjanie podjęli się również pracy duszpasterskiej w parafii ze względu na potrzebę lokalnego Kościoła. Na mocy aktu notarialnego z 20 marca 1927 roku nabyli plac o powierzchni $10170 \mathrm{~m}^{2} \mathrm{i}$ drewniany jednopiętrowy budynek za $38000 \mathrm{zł}$. Biskup W. Tymieniecki wyasygnował na ten cel $30000 \mathrm{zł}$, a salezjanie na remont domu i zakup przyległego placu $40000 \mathrm{zl}$. W zaadaptowanym budynku utworzono oratorium i małą kaplicę. Salezjanie kupili na Chojnach stary modrzewiowy kościól, który rozebrano i postawiono na terenie nowej parafii. W dniu 16 października 1927 roku kard. A. Hlond poświęcił świątynię, a 19 lipca 1928 roku biskup łódzki ustanowił parafię pw. św. Teresy od Dzieciątka Jezus. Na jej terenie mieszkało prawie 5000 wiernych. Ksiądz generał Filip Rinaldi 13 stycznia 1931 roku erygował dom zakonny pw. św. Teresy od Dzieciątka Jezus ${ }^{24}$.

Od października 1940 do stycznia 1945 roku kościół był zamknięty i przeznaczony przez Niemców na magazyn. W latach 1950-1961 wybudowano nową monumentalną świątynię na planie krzyża greckiego o wymiarach $50 \times 50$ m nakrytą kopułą o średnicy $32 \mathrm{~m}$ i wysokości 53,2 m. Władze państwowe dwa razy wydawały zakaz prowadzenia prac bez podania uzasadnionej przyczyny. Wewnętrzny wystrój (witraże, mozaiki, ołtarze, ławki, prospekt organowy) był projektowany i w znacznej części wykonany przez ks. Tadeusza Furdynę SDB. Dopiero w latach 1974-1978 wybudowano nową dwupiętrową plebanię. W latach 1978-1986 mieścił się w niej także zarząd Inspektorii św. Stanisława Kostki ${ }^{25}$.

Dużym wydarzeniem była inicjatywa ks. Jana Palusińskiego SDB przeglądu pieśni i piosenek religijnych „SACROSONG 69”. Festiwal ten odbył się 17 i 18 maja 1969 roku, a obecny był na nim kard. Karol Wojtyła. W kościele

${ }^{22}$ AAŁ, t. par. Matki Bożej Wspomożenia Wiernych, ks. insp. A. Świda do Kurii Biskupiej, Łódź 18 IV 1968; Dekret z 29 IV 1978 obowiązujący od 24 V 1978, L. dz. 436/78; M. Kwietniewski, Parafia Matki Bożej Wspomożenia Wiernych w Łodzi do roku 1991, Łódź-Lublin 2002, s. 6, 10 (mps).

${ }^{23}$ ASIW, Kronika WSD TS Łódź.

${ }^{24}$ Por. AAŁ, t. Parafia św. Teresy w Łodzi, ks. A. Łatka do bpa W. Tymienieckiego, 29 XI 1927; ASIW, t. Łódź - Św. Teresa, Decretum canonicae erectionic Domus, 13 I 1931, N. 202; „Pokłosie Salezjańskie”, 11 (1927) nr 11, s. 321; S. Łukaszewski, Na pamiątkę konsekracji dzwonów kościelnych parafii św. Teresy w Łodzi, Łódź 1931, s. 7.

${ }^{25}$ Por. J. Pietrzykowski, Salezjanie w Polsce 1945-1989, Warszawa 2007, s. 209. 
zorganizowano też Salezjański Ogólnopolski Kongres Misyjny (1-3 X 1976) połączony z odpustem parafialnym ${ }^{26}$.

W duszpasterstwie parafialnym salezjanie realizowali zalecenia władz diecezjalnych, a w niektórych dziedzinach byli wręcz pionierami, co zostało zauważone przez Wydział do Spraw Wyznań. „Zakony męskie na terenie miasta nie przejawiają, z wyjątkiem parafii salezjańskiej, tendencji do wykraczania poza tradycyjne normy działalności”27. Ks. Roman Żak zainicjował Duszpasterstwo Niewidomych działające w latach 1959-1975. W roku 1968 powstał też przy kościele salezjańskim pierwszy w Łodzi Klub Inteligencji Katolickiej, który po czterech latach przeniesiono do katedry. Od 1964 roku prowadzone jest Duszpasterstwo Akademickie „Węzeł”. Duszpasterz studentów prowadzi od 1991 roku księgarnię salezjańską. Ponadto salezjanie obsługują jako kapelani dwa szpitale, areszt śledczy i uczą religii w trzech szkołach podstawowych i dwóch średnich na terenie parafii. W 1991 roku w świątyni oddano do użytku nowe 66-głosowe organy koncertowe. Od tego czasu w kwietniu lub maju odbywały się festiwale organowe pod patronatem Akademii Muzycznej ${ }^{28}$.

Lutomiersk to niewielka miejscowość licząca ok. 1800 mieszkańców w województwie łódzkim, położona na lewym brzegu Neru, 17 km na zachód od Łodzi, przy szosie Zgierz-Kalisz. W latach $1274-1870$ posiadał on prawa miejskie. Od 1283 roku istniała tu parafia rzymsko-katolicka ${ }^{29}$. Wojewoda rawski Andrzej Grudziński w połowie XVII wieku przyczynił się do sprowadzenia nad Ner franciszkanów-reformatów i ofiarował zakonnikom swój zamek na klasztor. Jego następcy rozbudowali klasztor i zbudowali barokowy kościół ${ }^{30}$. Franciszkanie-reformaci mieszkali w Lutomiersku do roku 1900, a następnie przez niecały rok 1919/1920 ${ }^{31}$.

${ }^{26}$ Archiwum Państwowe w Łodzi (dalej: APŁ), sygn. 1593, Wydział do Spraw Wyznań w Łodzi do Urzędu do Spraw Wyznań w Warszawie, Sprawozdanie z przebiegu festiwali, Łódź 19 V 1969; A. Gabrel, Salezjański Ogólnopolski Kongres Misyjny, „Nostra. Biuletyn Salezjański”, 31 (1976) nr 9(158), s. 2-58.

${ }^{27}$ APŁ, sygn. 1548, Ud/sW do Ud/sW, Łódź 19 IV 1963.

${ }^{28}$ Kronika domu i parafii św. Teresy; J. Pietrzykowski, 70-lecie parafii św. Teresy $w$ Lodzi, „Niedziela”, (1998) nr 47(294)B, s. 1.

${ }^{29}$ Por. R. Rosin, Studia z dziejów miast dawnych województwa tęczyckiego i sieradzkiego (XII-XVI w.), Łódź 1959, s. 10.

${ }^{30}$ Baltazar Lutomirski, właściciel Lutomierska, w roku 1570 przekazał kościół rzymsko-katolicki wyznawcom ewangelicko-reformowanym na zbór i przez 80 lat świątynia była w rękach kalwinów. A. Grudziński nawróciwszy się z kalwinizmu, zwrócił kościół katolikom i w ramach ekspiacji sprowadził Braci Mniejszych Reformatów do Lutomierska. Por. Archidiecezja Łódzka, Łódź 1992, s. 134; J. Pietrzykowski, Salezjanie w Lutomiersku wczoraj a dziś, „Seminare”, 12 (1996) s. 292-294.

${ }^{31}$ Po kasacie przeprowadzonej w 1864 w Królestwie Polskim klasztor w Lutomiersku pełnił rolę klasztoru etatowego, do którego przywieziono zakonników wysiedlonych z Brzezin, Miedniewic i Szczawina. Po odzyskaniu przez Polskę niepodległości biskup kujawsko-kaliski sprowadził czterech franciszkanów-reformatów z Krakowa. Zakonnicy zrażeni ruinami kościoła i klasztoru oraz piętrzącymi się trudnościami zrezygnowali z obsługi miejscowej parafii i dalszego pobytu w Lutomiersku. Por. G. Wiśniowski, Franciszkanie - reformaci w latach 1772-1970, w: Zakony św. Franciszka w Polsce w latach 1772-1970, red. J.R. Bar, cz. 3, Warszawa 1978, s. 179-181; R. Prejs, Zakonnicy franciszkańscy Królestwa Polskiego po kasacie 1864 roku. Dzieje-postawy, Kraków 2003, s. 102-104. 
Towarzystwo Salezjańskie na prośbę biskupa łódzkiego przejęło odbudowany ze zniszczeń wojennych kościół i ruiny klasztoru. Ponadto w skład mienia wchodziło kilka budynków gospodarczych, 2,8 ha ziemi razem z placem, stawami, olszynką i ogrodem otoczonym murem z cegły. Uroczystość wprowadzenia salezjanów w obecności bp. W. Tymienieckiego i duchowieństwa odbyła się 13 czerwca 1926 roku podczas odpustu. Przełożony generalny bł. ks. Filip Rinaldi 27 czerwca 1927 roku erygował dom zakonny pw. św. Franciszka Salezego ${ }^{32}$. Salezjanie zajęli się odbudową klasztoru i przystosowaniem go jako siedziby dla przyszłego sierocińca (domu dziecka) dla chłopców. Systematycznie powiększano powierzchnię mieszkalną, doprowadzono wodę, założono centralne ogrzewanie, zwiększono liczbę natrysków i sanitariatów. W roku szkolnym 1928/1929 w sierocińcu przebywało 60 wychowanków, a rok później było ich 110 i ta liczba utrzymała się do wybuchu II wojny światowej ${ }^{33}$. Podczas okupacji niemieckiej sierociniec funkcjonował do listopada 1939 roku i od kwietnia 1940 roku do 23 kwietnia 1941 roku. Opiekę nad 87 chłopcami pełniło trzech księży, czterech koadiutorów (braci zakonnych) i kilku kleryków. Po jego likwidacji został zamknięty kościól, klasztor Niemcy przeznaczyli na własne potrzeby, a salezjanie (ksiądz i koadiutor) zamieszkali w domku dla ogrodnika. W dniu 20 stycznia 1945 roku po wkroczeniu do Lutomierska Armii Czerwonej Rosjanie nakazali mieszkańcom wysprzątać kościół i następnego dnia w niedzielę ks. Ludwik Rupala odprawił dwie Msze św. i nieszpory ${ }^{34}$.

Salezjański Dom Dziecka w Lutomiersku działał do 1951 roku, a przebywało w nim 60-80 chłopców. Pożar klasztoru 11 września 1951 roku przyczynił się do likwidacji tej placówki wychowawczej. Po odbudowie obiekt klasztorny przeznaczono na dom rekolekcyjny. Dodatkowo w latach 1982-1990 przebywali w nim klerycy i kandydaci do zgromadzenia, którzy uzupełniali wykształcenie w zakresie szkoły średniej. W 1994 roku Zarząd Gminy Lutomiersk przekazał salezjanom Ośrodek Rekreacyjny dla Młodzieży. Od 1996 roku Towarzystwo Salezjańskie prowadzi szkołę organistowską z internatem (Salezjańskie Liceum Muzyczne im. ks. Antoniego Chlondowskiego) ${ }^{35}$.

${ }^{32}$ AAŁ, t. Lutomiersk, bp W. Tymieniecki do ks. insp. Antoniego Hlonda, Łódź 7 XII 1925; ASIW, t. Lutomiersk, Dekret erekcyjny domu 27 Junii 1927 Nr 59; Archiwum Domu w Lutomiersku, Spis inwentarza klasztornego w Lutomiersku; Zakład salezjański w Lutomiersku, „Pokłosie Salezjańskie", 12 (1928) nr 1, s. 47.

${ }^{33}$ Archiwum Domu w Lutomiersku, Księga Pamiątkowa Odbudowy Klasztoru w Lutomiersku, s. 60 (rękopis), J. Romanowicz, Krótka historia klasztoru w Lutomiersku i kronika domu zakonnego 1926-1939, s. 16-18 (rękopis); J. Krzemiński, Lutomiersk na przestrzeni dziejów, Lutomiersk 1974, s. 79,89 .

${ }^{34}$ ASIW, t. Lutomiersk, L. Rupala, Wspomnienia o Lutomiersku z czasów wojny, Sokołów Podlaski 1963, s. 2-11 (mps).

${ }^{35}$ ASIW, Protokoły posiedzeń rad inspektorialnych 1946-1950, 2 IV 1946, 8-9 X 1946; t. Zjazdy dyrektorów i proboszczów, S. Rokita, Obecny stan Inspektorii św. Stanisława Kostki i zamierzenia na przyszłość, Aleksandrów Kujawski 9-12 VIII 1949; t. Lutomiersk, ks. J. Padurek do współbraci, Lutomiersk IX 1951, Protokół wizytacji kanonicznej, 29 XII 1983; Archiwum Domu w Lutomiersku, Księga Ogłoszeń Duszpasterskich za lata 1975-1997; J. Pietrzykowski, Salezjanie w Lutomiersku, s. 307-310. 
Zgierz. W 1981 roku inż. Hieronim Rymkiewicz ofiarował salezjanom grunt pomiędzy Zgierzem a Łodzią. Wybudowano małą kaplicę, którą 4 kwietnia 1982 roku poświęcił bp Bohdan Bejze, a salezjanie rozpoczęli duszpasterstwo na terenie parafii św. Antoniego w Łagiewnikach. Na stałe mieszkał tam jeden lub dwóch księży, którzy obsługiwali ok. 280 rodzin. Salezjanie dojeżdżali też do Domu Pomocy Społecznej przy ul. Chełmskiej na terenie par. Matki Bożej Dobrej Rady w Zgierzu. W latach 1987-1991 zbudowano nową plebanię, przeznaczając część budynku na oratorium dla młodzieży. W roku 2017 salezjanie nie widząc perspektyw rozwoju placówki, zrezygnowali z pracy w Zgierzu, sprzedając Kurii Arcybiskupiej w Łodzi nieruchomość ${ }^{36}$.

\section{Zakon Braci Bosych Najświętszej Maryi Panny z Góry Karmel (karmelici bosi)}

Łódź. Karmelici Bosi to zakon o charakterze kontemplacyjno-czynnym, powstały w połowie XVI wieku w Hiszpanii na skutek reformy zakonu karmelitów przeprowadzonej przez św. Teresę Wielką i św. Jana od Krzyża. W 1605 roku założyli klasztor w Krakowie, a pod koniec XVIII wieku mieli w Rzeczypospolitej dwie prowincje zakonne: polską i litewską, liczące razem ok. 500 profesów skupionych w 29 klasztorach $^{37}$.

Od 1928 roku karmelitanki bose mieszkały w Łodzi na Radogoszczy przy ul. Zgierskiej. Pragnęły one mieć stałą opiekę duchową prowadzoną przez księży z ich rodziny zakonnej. Prowincjał o. Józef Prus szukając możliwości założenia klasztoru w dużym mieście, zdecydował się na Łódź, przez co wyszedł naprzeciw potrzebom sióstr kontemplacyjnych. W 1945 roku zainteresował się on opuszczonym przez ewangelików niemieckich jednonawowym zborem wymurowanym w 1935 roku, plebanią i gruntem o powierzchni ponad 2 ha przy zbiegu ulic św. Michała i Liściastej w Gminie Radogoszcz. Nieruchomość należała do Parafii Ewangelicko-Augsburskiej w Zgierzu. Po przejściu frontu wojennego na zachód i wyjeździe Niemców własność protestancką potraktowano jako mienie porzucone. Na tej podstawie prawnej o. J. Prus 7 maja 1945 roku zwrócił się do Zarządu Gminy Radogoszcz z prośbą o przydzielenie karmelitom bosym niedokończonego kościoła, budynków i ogrodu. Zarząd Gminy poparł ten projekt i przekazał zbór na użytek Kościoła katolickiego. Następnie Główny Urząd Tymczasowego Zarządu Państwowego wydał prowincjałowi prawomocną decyzję o przekazaniu opuszczonego i porzuconego majątku nieruchomego i ruchomego ${ }^{38}$.

Kuria biskupia przyjęła postawę wyczekującą, a bp Włodzimierz Jasiński wprost nie wyraził zgody na poświęcenie zboru i otwarcie domu zakonnego, uzasadniając decyzję tym, że karmelici bosi nie posiadali jeszcze aktu własno-

${ }^{36}$ ASIW, t. Łódź-Kuria, ks. insp. W. Szulczyński do bp. J. Rozwadowskiego, Łódź 31 III 1981; Kronika Zgierz-Chełmy.

${ }^{37}$ Por. Cz. Gil, Karmelici Bosi, w: Encyklopedia katolicka, t. 8, red. B. Migut, Lublin 2000, kol. 814-819.

${ }^{38}$ Por. B.J. Wanat, Zakon Karmelitów Bosych w Polsce. Klasztory karmelitów i karmelitanek bosych 1605-1975, Kraków 1979, s. 592-593. 
ści ${ }^{39}$. Dlatego też miejscowy gwardian o. Elizeusz Trzeciak 28 czerwca 1945 roku samowolnie poświęcił budynek przeznaczony do kultu i rozpoczął odprawianie nabożeństw dla wiernych. Dopiero wikariusz generalny, biskup pomocniczy K. Tomczak, pismem z 29 maja 1947 roku przyjął karmelitów bosych do diecezji i pozwolił im na stałe osiedlić się w Łodzi ${ }^{40}$. Zakonnicy dokończyli budowę kościoła i systematycznie wyposażali jego wnętrze oraz wyremontowali zdemolowaną podczas okupacji plebanię. Koszt tych inwestycji kilkakrotnie przewyższał wartość przejętego mienia. Był to poważny argument w procesie sądowym prowadzonym w latach 1955-1958 z Parafią Ewangelicką w Zgierzu o zwrot majątku. Po pozytywnej decyzji sądowej 30 czerwca 1960 roku Zakon Karmelitów Bosych za cenę $710000 \mathrm{zł} \mathrm{kupił} \mathrm{od} \mathrm{Parafii} \mathrm{Ewangelicko-Augsburskiej} \mathrm{w} \mathrm{Zgierzu}$ nieruchomość w Łodzi na Radogoszczu przy ul. Liściastej ${ }^{41}$. Na mocy specjalnych uprawnień Stolicy Apostolskiej prymas Polski kard. Stefan Wyszyński dekretem z 24 maja 1961 roku erygował dom zakonny pw. św. Józefa. Po wyposażeniu wnętrza świątyni bp J. Rozwadowski 20 marca 1972 roku konsekrował kościół pw. św. Józefa, a 14 listopada 1974 erygował przy nim parafię, którą powierzył karmelitom bosym ${ }^{42}$.

\section{Zgromadzenie Misjonarzy Oblatów Maryi Niepokalanej (oblaci)}

Grotniki. Oblaci to zgromadzenie zakonne założone w 1816 roku we Francji przez św. Eugeniusza de Mazenod. Ich charyzmatem jest ewangelizacja opuszczonych poprzez duszpasterstwo ogólne i prowadzenie misji. Do Polski przybyli w roku 1919 z prowincji niemieckiej i rok później założyli w Krotoszynie pierwszą placówkę̧3.

Misjonarze oblaci sami wystąpili z inicjatywą osiedlenia się w Łodzi lub jej okolicach. Praca w parafii lub przy kościele rektoralnym umożliwiałaby im kontakt z miejscowych duchowieństwem i wiernymi, a w klasztorze mieszkaliby misjonarze ludowi i rekolekcjoniści ${ }^{44}$. W 1946 roku oblaci przybyli do Grotnik, wioski letniskowej, przy której od roku 1925 istniała stacja kolejowa. Zakonnicy podjęli pracę duszpasterską przy jednonawowym kościele filialnym zbudowanym w 1933 roku, należącym do parafii św. Katarzyny w Zgierzu. Początkowo oblat ks. Roman Zając dojeżdżał do Grotnik z Łodzi, a od kwietnia 1947 roku zamieszkał w pałacyku Marii Jungowskiej w Grotnikach. Po odnowieniu świątyni bp Michał Klepacz 23 września 1951 roku erygował przy niej parafię pw. Niepokalanego Poczęcia NMP i przekazał ją Polskiej Prowincji Misjonarzy Oblatów. Na jej terenie

${ }^{39}$ AAŁ, sygn. 69, t. Karmelici Bosi Łódź, Bp W. Jasiński do o. prowincjała, Łódź 12 VIII 1945 , s. 1-3 (mps).

${ }^{40}$ AAt, sygn. 70, t. Karmelici Bosi, Akta procesu o klasztor.

${ }^{41}$ AAŁ, sygn. 70, t. Karmelici Bosi, Akta kupna klasztoru.

${ }^{42}$ AAŁ, sygn. 70, t. Karmelici Bosi, Dekret erekcji parafii, Łódź 14 XI 1974 L. dz. 1298/74; Sprawozdanie z wizytacji bp. Jana Kulika w rektoralnym kościele O. Karmelitów Bosych w Łodzi, Łódź 10 XI 1968, s. 1-5 (mps).

${ }^{43}$ Por. P. Zając, Fundacje klasztorów Misjonarzy Oblatów Maryi Niepokalanej w Archidiecezji Poznańskiej w latach 1922-1939, „Ecclesia, Studia z Dziejów Wielkopolski”, 5 (2010) s. 148-151.

${ }^{44}$ AAŁ, t. Misjonarze Oblaci Grotniki, Prowincjał do bp. M. Klepacza, Poznań 30 IX 1946. 
mieszka ok. 1800 wiernych ${ }^{45}$. Po długotrwałych zabiegach dopiero od 1956 roku parafia posiada własny cmentarz grzebalny. Poważniejsze inwestycje w kościele oblaci przeprowadzili w latach 2003-2004. Złożyły się na nie: budowa nowego prezbiterium, a obok niego zakrystii i kaplicy Miłosierdzia Bożego. W 2005 roku świątynię ozdobiono nową murowaną dzwonnicą ${ }^{46}$.

Wkrótce po erygowaniu parafii, 8 października 1951 roku przełożony generalny utworzył dom zakonny pw. Niepokalanego Poczęcia NMP. Do roku 1954 zakonnicy zbudowali klasztor, do którego w 1982 roku dobudowano jedną kondygnację i obszerne poddasze ${ }^{47}$.

Drugim miejscem pracy duszpasterskiej, które usiłowali zorganizować oblaci, był poewangelicki kościół św. Józefa Robotnika w Konstantynowie. W latach 1948-1968 księża uczyli dzieci religii w szkołach i salach katechetycznych. Z powodu trudnych warunków mieszkaniowych i materialnych oraz nieporozumień z miejscowym księdzem proboszczem i dziekanem odnośnie wynagrodzenia za wykonywaną pracę i udostępnianie lokali w 1968 roku definitywnie opuścili Konstantynów ${ }^{48}$.

\section{Zgromadzenie Męki Pana Naszego Jezusa Chrystusa (pasjoniści)}

Łódź. Pasjoniści zostali założeni w 1720 roku we Włoszech przez św. Pawła od Krzyża w celu propagowania nabożeństwa Męki Pańskiej. Do Polski przybyli w 1923 roku i objęli pobernardyński kościół i klasztor w Przasnyszu na terenie diecezji płockiej. W okresie międzywojennym zorganizowali jeszcze dwa domy zakonne: w Rawie Mazowieckiej i w Sadowiu koło Ostrowa Wielkopolskiego ${ }^{49}$.

Wzrost liczby powołań i wyświęcenie pierwszych księży pasjonistów w latach 50. XX wieku przyczyniły się do rozwoju Zgromadzenia Pasjonistów w Polsce. Ich największym osiągnięciem było założenie placówki w Łodzi, za zgodą bpa Michała Klepacza. W dniu 25 października 1956 roku Kuria Biskupia w Łodzi wydała pozwolenie na budowę kościoła i plebaniii ${ }^{50}$. Pasjoniści w dzielnicy Bałuty-Teofilów usytuowanej w północno-wschodniej części Łodzi przy ul. Traktorowej kupili plac od osoby prywatnej i 28 października 1958 roku spisano akt notarialny w Państwowym Biurze Notarialnym w Zgierzu. Pierwszą wspólnotę zakonną tworzyło dwóch księży i brat zakonny, którzy mieszkali w wynajętym domu. Na swojej posesji bez wiedzy i zgody władz państwowych postawili małą kaplicę. Po dwóch tygodniach, w dniu 2 grudnia 1957 roku, została ona zamknię-

${ }^{45}$ Por. Informator życia konsekrowanego, s. 46. Historia wsi Grotniki - Misjonarze Oblaci, $\mathrm{http} / /$ doczc.pl/doc/2100278/historia-wsi-grotniki-misjonarze-oblaci (dostęp: 21.07.2017).

${ }^{46}$ Grodniki - Parafia pw. Niepokalanego poczęcia, https://archive.is/D5mV (dostęp: 21.07.2017).

${ }^{47}$ Por. AAŁ, sygn. 75, t. Misjonarze Oblaci, Grotniki, Referent do spraw statystycznych. W 1957 roku w klasztorze mieszkało 5 księży i 2 braci; Historia wsi Grotniki.

${ }^{48}$ AAt, sygn. 74, t. Misjonarze Oblaci, Konstantynów, ks. prowincjał S. Śmigielski do bp. M. Klepacza, Poznań 25 III 1948; 31 III 1948; o. prowincjał do ks. J. Kamińskiego, Poznań 23 I 1961 L. dz. 7/61.

${ }^{49}$ Por. H.D. Wojtyska, Historia Zgromadzenia Pasjonistów w Polsce, t. 1, Łódź 2006, s. 23, 134-138.

${ }^{50}$ AAŁ, OO. Pasjoniści, sygn. 70, List do Prowincjała, Łódź 25 X 1956. 
ta, opieczętowana i objęta nakazem zburzenia. Najskuteczniej w obronie pasjonistów stanęli mieszkańcy Teofilowa, którzy zaczęli domagać się budowy kościoła. W tym trudnym początkowym okresie w latach 1958-1959 zakonnikom udało się postawić budynek mieszkalny, zabudowania gospodarcze oraz uzyskać zameldowanie w klasztorze. Z powodu zwiększającej się liczby wiernych i trudności lokalowych, w połowie lat 60. przystosowano budynki gospodarcze do katechizacji i kancelarii. W niedziele i święta Msze św. odprawiano na zewnątrz przy polowym ołtarzu, a część podwórka zabezpieczono prowizorycznym dachem. W roku 1969 bp J. Rozwadowski utworzył przy kaplicy samodzielny wikariat z prawem pełnienia wszystkich funkcji parafialnych. Wypada nadmienić, że był to jedyny ośrodek kultu na Teofilowie, gdzie mieszkało ok. 60000 osób $^{51}$. Po wielu trudnościach, 23 grudnia 1971 roku Prezydium Miejskiej Rady Narodowej w Lodzi zatwierdziło lokalizację kościoła. Budowę nowej świątyni rozpoczęto 14 czerwca 1972 roku i tego dnia wszedł w życie dekret biskupa diecezjalnego z 3 czerwca br. ustanawiający parafię Matki Bożej Bolesnej włączoną do dekanatu Łódź-Zachód. Nową jednostkę duszpasterską obsługiwało pięciu księży zakonnych, którzy rocznie przygotowywali: do I Komunii Św. ok. 1000 dzieci, 500 osób do bierzmowania, a ok. 4000 dzieci i młodzieży obejmowali katechizacją ${ }^{52}$.

Pasjoniści zbudowali nowy klasztor połączony z dwukondygnacyjnym kościołem na planie sześcioboku $z$ dołączoną kaplicą i wieżą oraz nieregularną kruchtą stanowiącą łącznik pomiędzy górną i dolną świątynią oraz dzwonnicą. Projekt tego kompleksu budowlanego zaprojektowali dwaj architekci: Leszek Łukoś i Ludwik Mackiewicz. W dniu 29 maja 1976 roku poświęcono niewykończony jeszcze kościół parafialny, a jego uroczysta konsekracja odbyła się 17 kwietnia 2006 roku. Granice tej dużej parafii zmniejszyły się w 1983 roku i w latach 90. $\mathrm{XX}$ wieku ${ }^{53}$.

W 1990 roku w związku z powrotem nauki religii do szkół wolne pomieszczenia przełożeni zakonni przeznaczyli na dom formacyjny dla kleryków i braci zakonnych. Alumni dojeżdżali na wykłady, seminaria i ćwiczenia do łódzkiego Wyższego Seminarium Duchownego, a okresowo w latach 1996-1999 do Wyższego Seminarium Dychownego Towarzystwa Salezjańskiego przy ul. Wodnej ${ }^{54}$.

\section{Kongregacja Oratorium św. Filipa Neri (filipini)}

Tomaszów Mazowiecki. Filipinów zorganizował w 1575 roku w Rzymie św. Filip Neri. Jest to Stowarzyszenie Życia Apostolskiego, którego członkowie nie składają ślubów, ich domy są autonomiczne i poddane ograniczonej jurysdykcji miejscowego biskupa. Do Polski przybyli w 1668 roku i zorganizowali pierwsze oratorium w Głogówku pod Gostyniem na terenie diecezji poznańskiej. Głównym

${ }^{51}$ Por. Kościoły Archidiecezji Łódzkiej - Nasze Dziedzictwo, t. 1, Łódź 2010, s. 192; Ł. Andrzejewski, Dzieje Pasjonistów w Polsce w latach 1945-1990, Warszawa 2015, s. 52-56 (mps).

${ }^{52}$ AAŁ, sygn. 70, OO. Pasjoniści, Dekret z 3 VI 1972, sygn. D.41; Łódź par. MB Bolesnej 1969-1981, sygn. 149, Sprawozdanie duszpasterskie, Łódź 23 II 1971.

${ }^{53}$ Por. R. Wróbel, Nowe kościoły w diecezji łódzkiej 1945-1989, Łódź 2005, s. 103.

${ }^{54}$ Por. Kronika WSD TS Łódź. 
zadaniem filipinów jest duszpasterstwo i wychowanie młodzieży ${ }^{55}$.

W latach 1969-1971 na prywatnej działce w Tomaszowie Mazowieckim przy ul. Niskiej nr 81 filipini zbudowali jednorodzinny dom, garaż i suszarnię owoców, którą w 1971 roku zaadaptowali na salę katechetyczną. Rok później bp J. Rozwadowski zezwolił im na codzienne odprawianie Mszy św. i otwarcie kaplicy pw. Świętej Rodziny ${ }^{56}$. Następnie w latach 1981-1984 według projektu architekta Jerzego Dobrzańskiego filipini zbudowali jednonawowy kościół z wieżą, który 21 października 1990 roku konsekrował bp W. Ziółek. Pod koniec XX wieku przed świątynią wymurowano dzwonnicę. W dniu 18 listopada 1976 roku Kuria Biskupia w Łodzi utworzyła rektorat i określiła granice przyszłej parafii. Dekretem biskupim z dnia 18 grudnia 1980 roku została erygowana Kongregacja (dom zakonny), a 20 grudnia 1980 roku bp J. Rozwadowski utworzył parafię pw. Świętej Rodziny i przyłączył ją na stałe do Kongregacji Oratorium. W 1987 roku oddano do użytku nowy budynek klasztorny. Na terenie parafii mieszka ok. 6000 osób. Obowiązki proboszcza pełni przełożony Kongregacji, a w pracy duszpasterskiej wspomaga go wikariusz parafialny i inni księża mieszkający w domu zakonnym. Od 19 lipca 2014 roku filipini prowadzą w Tomaszowie Mazowieckim Językowe Katolickie Przedszkole im. św. Filipa Neri ${ }^{57}$.

\section{Bracia Serca Jezusowego}

Łódź. Bracia Serca Jezusowego to zgromadzenie zakonne, niekleryckie, na prawie diecezjalnym, zatwierdzone w 1923 roku przez prymasa Polski kard. Edmunda Dalbora. Ich zadaniem jest pomoc w pracy różnych instytucji kościelnych ${ }^{58}$.

W marcu 1979 roku z inicjatywy bp. Jana Kulika, proboszcza parafii Najświętszego Serca Jezusowego w Łodzi-Julianowie, na plebanii zamieszkali dwaj Bracia Serca Jezusowego. Prowadzili oni w kościele grupę ok. 140 ministrantów, dodatkowo pomagali w ogrodzie i na budowie. Biskup liczył na zwiększenie obsady personalnej przez Zgromadzenie, ale przełożony generalny przeprowadzał częste zmiany i ostatecznie na parafii pozostawił tylko jednego brata zakonnego. Podane powyżej okoliczności przyczyniły się w 1984 roku do wycofania się Braci Serca Jezusowego z pracy w Łodzi ${ }^{59}$.

${ }^{55}$ Por. J. Nowacki, Dzieje Archidiecezji poznańskiej, t. 2: Archidiecezja poznańska w granicach historycznych i jej ustrój, Poznań 1964, s. 770-771; H. Jaromir, Zarys historii Kongregacji Oratorium świętego Filipa Neri w Polsce 1668-1968, NP, 32(1970) s. 10-11.

${ }^{56} \mathrm{KWPZ}$, t. Filipini-Oratorianie, ks. T. Adamus do bp. B. Dąbrowskiego, Tomaszów Mazowiecki 30 X 1973, s. 1-3 (mps).

${ }^{57}$ Dekret erekcji parafii pw. Świętej Rodziny w Tomaszowie Mazowieckim, L. dz., 1996/80, „Wiadomości Diecezjalne Łódzkie”, 55 (1981) nr 1-2, s. 21-22; www.filipini.vernet.pl/historia/6-historia.html (dostęp: 22.07.2017).

${ }^{58}$ Por. J. Bar, Bracia Serca Jezusowego, w: Encyklopedia katolicka, t. 2, red. F. Gryglewicz, Lublin 1985, kol. 1006; R. Szpakowski, Zgromadzenie Braci Serca Jezusowego w Polsce w latach 1923-1983, Warszawa 1986, s. 27-28.

${ }^{59}$ AAŁ, sygn. 41, t. Bracia Serca Jezusowego, Łódź, Umowa o pracę 8 X 1979 pomiędzy Parafią Najświętszego Serca Jezusowego w Łodzi a Zgromadzeniem Serca Jezusowego, Łódź, s. 1-3 (mps); Br. Janusz Supady, Historia placówki Braci Serca Jezusowego w Łodzi Julianowie, 2007, 


\section{Zgromadzenie Misjonarzy Synów Niepokalanego Serca Błogosławionej Dziewicy (klaretyni)}

Łódź. Klaretyni zostali założeni w 1848 roku w Vic w Hiszpanii przez biskupa św. Antoniego Marię Klareta (1807-1870). W 1932 roku założyli placówkę w Miedarach, w archidiecezji wrocławskiej. Po II wojnie światowej z braku duchowieństwa diecezjalnego w Administracji Apostolskiej Śląska Opolskiego klaretyni podjęli pracę duszpasterską w okolicznych parafiach. Od roku 1974 mieli dom zakonny we Wrocławiu, który wkrótce został siedzibą Polskiej Delegatury Zarząu Generalnego ${ }^{60}$.

Początki klaretynów w Łodzi sięgają roku 1986, kiedy dwóch księży zgromadzenia podjęło pracę duszpasterską jako wikariusze w parafii Wniebowzięcia NMP. Wkrótce kolejni klaretyni zostali oddelegowani do pomocy w parafii Matki Boskiej Jasnogórskiej na Widzewie-Wschód i w parafii Miłosierdzia Bożego. W tym okresie przełożony Delegatury Zarządu Generalnego ks. Stanisław Piórkowski rozpoczął starania o utworzenie parafii klaretyńskiej w Lodzi. W dniu 28 września 1989 roku bp W. Ziółek utworzył parafię pw. Niepokalanego Serca NMP i św. Antoniego Marii Klareta na Teofilowie i powierzył ją klaretynom. Już 15 grudnia 1989 roku uzyskano plac pod budowę. Władze diecezjalne przekazały zakonnikom dom przy ul. Szczecińskiej do czasu wzniesienia własnych budynków. Pierwsze Msze św. dla parafian klaretyni odprawiali w Domu Kultury „Lutnia”, w kościele Matki Boskiej Bolesnej i kościele Miłosierdzia Bożego. Lokal dla kancelarii parafialnej wypożyczyli ojcowie pasjoniści ${ }^{61}$. W dniu 29 kwietnia 1990 roku bp Ziółek poświęcił krzyż i plac budowy, na którym postawiono wiatę i ołtarz polowy wykorzystywany w okresie letnim. W dniu 27 października 1991 roku biskup łódzki poświęcił nową kaplicę i budynek mieszkalny dla wspólnoty klaretynów, przez co opuścili oni dom przy ul. Szczecińskiej. Wiosną 1993 roku przystąpiono do budowy trójnawowego kościoła. Mimo prowadzonych prac wykończeniowych od 12 kwietnia 2001 (Wielki Czwartek), w kościele rozpoczęto sprawowanie liturgii. Jednocześnie w latach 2003-2007 zbudowano dom zakonny połączony z kościołem wraz z budynkiem parafialnym. W 2001 roku na terenie parafii klaretynów mieszkało 12000 osób, a w roku 2015 liczba mieszkańców zmalała do 8350 osób $^{62}$.

s. $1-3$ (mps).

${ }^{60}$ Ważnym wydarzeniem w rozwoju klaretynów w Polsce było ustanowienie 16 XI 1982 Polskiej Delegatury Niezależnej, a następnie 5 XI 1993 Prowincji Polskiej. W dekrecie erekcyjnym zostali wymienieni także polscy klaretynki pracujący w Wybrzeżu Kości Słoniowej, Syberii, Białorusi i w Niemczech. Por. Misjonarze Klaretyni 1807-2007 śladami ojca Klareta. Zarys historii Zgromadzenia Misjonarzy Klaretynów C. M. E., oprac. i red. K. Gierat, Warszawa 2007, s. 145-150.

${ }^{61}$ Archiwum Kurii Prowincjalnej Misjonarzy Klaretynów w Warszawie, t. Łódź, Akt Notarialny 12 III 2003 r. Repertorium A nr 1506/2003; Umowa między Archidiecezją Łódzką reprezentowaną przez ks. abp. Władysława Ziółka Metropolitę Łódzkiego i Polską Prowincję Misjonarzy Klaretynów, reprezentowaną przez Ojca Prowincjała Krzysztofa Gierata CMF w sprawie powierzenia na stałe parafii Niepokalanego Serca NMP i św. Antoniego Marii Klareta w Łodzi, Łódź 22 VI 2004; Komunikat biskupa ordynariusza o nowych parafiach w diecezji łódzkiej, „Wiadomości Diecezjalne Łódzkie”, 63 (1989) nr 9-10, s. 268-269; Historia Parafii, http://www.parafia.klaretyni.pl/historia (dostęp: 08.07. 2017).

${ }^{62}$ Por. 25-lecie klaretyńskiej Parafii Niepokalanego Serca NMP i św. Antoniego Marii Klareta w Łodzi, Łódź 2014. 


\section{Zgromadzenie Księży Najświętszego Serca Jezusowego (sercanie)}

Bełchatów. Powołaniem sercanów jest oddawanie czci Najświętszemu Sercu Jezusowemu i wynagradzanie za grzechy. Ich założycielem jest ks. Jan Leon Dehon, który pierwszą wspólnotę zorganizował w 1878 roku w Saint Quentin. Do Polski sercanie przybyli w 1928 roku i początkowo osiedlili się w Krakowie-Płaszowie ${ }^{63}$.

Na podstawie umowy zawartej 7 września 1982 roku pomiędzy biskupem łódzkim a prowincjałem sercanów przybyli oni do Bełchatowa. Na obrzeżach nowego robotniczego osiedla, zamieszkałego głównie przez pracowników kopalni węgla brunatnego i elektrowni, w 1983 roku przejęli ośmiotysięczną parafię pw. Najświętszej Maryi Panny Matki Kościoła, w której trwała budowa kościoła. Kamień węgielny świątyni wmurowano 14 grudnia 1982 roku, a kościół w stanie surowym został oddany do użytku na pasterkę 1987 roku, natomiast 1 czerwca 1998 roku odbyła się uroczysta konsekracja świątyni ${ }^{64}$. W roku 1984 księża mieszkający w wynajętych lokalach przenieśli się do nowo wybudowanej plebanii. Wtedy też erygowano filię domu zakonnego, a dopiero w roku 1995 zmieniono jego status na dom główny. Na prośbę duszpasterzy i parafian 4 grudnia 1993 roku abp W. Ziółek ogłosił św. Barbarę drugą patronką parafii. Ważnym wydarzeniem w życiu wspólnoty było w 1996 roku oddanie do użytku Domu Parafialnego, który został przeznaczony dla grup duszpasterskich i na mieszkanie Sióstr Służek Maryi Niepokalanej ${ }^{65}$.

\section{Zgromadzenie Braci Szkół Chrześcijańskich (bracia szkolni)}

Łódź, Pabianice, Piotrków Trybunalski. Zgromadzenie braci szkolnych zostało założone ok. 1680 roku w Remis we Francji przez św. Jana de La Salle. Ich głównym zadaniem było objęcie edukacją dzieci i młodzieży pozbawionych możliwości zdobycia nawet wykształcenia podstawowego. Dzięki pomocy św. ks. Zygmunta Gorazdowskiego w 1903 roku przybyli do Lwowa i zorganizowali polsko-niemiecką szkołę. Od roku 1922 pracowali w Częstochowie, ale już w 1948 roku władze komunistyczne odebrały im szkołę i internat, a braci pracujących w charakterze nauczycieli i wychowawców pozbawiły możliwości wykonywania zawodu $^{66}$.

${ }^{63}$ Por. E. Ziemann, Sercanie, w: Encyklopedia katolicka, t. 18, red. E. Gigilewicz, Lublin 2013, kol. 2-4; J. Furczoń, Początki Zgromadzenia Księży Sercanów w Polsce, w: Uwierzyliśmy miłości. 75 lat obecności Zgromadzenia Księży Sercanów w Polsce 1928-2003. Księga Jubileuszowa, red. G. Pisarek, Kraków 2004, s. 36-37.

${ }^{64}$ Archiwum Prowincjalne Zgromadzenia Sercanów w Warszawie, Informator SCJ 25 VIII 1982, s. 47 (mps), 30 XII 1982, s. 99 (mps); AAŁ, Bracia Szkolni Piotrków Trybunalski, sygn. 98, Umowa między bp. J. Rozwadowskim a ks. prowincjałem A. Czają, Łódź 30 IX 1983, s. 1-10 (mps), Elenchus Polskiej Prowincji Zgromadzenia Księży Najświętszego Serca Jezusowego 2016, Kraków 2016, s. 83.

${ }^{65}$ Władze miasta Bełchatowa nie wydały pozwolenia na budowę świątyni w centrum powstającego osiedla. Dlatego wykupiono plac na jego obrzeżu i 15 VIII 1981 bp J. Rozwadowski erygował parafię, którą początkowo prowadzili księża diecezjalni i rozpoczęli budowę kościoła według projektu architekta Włodzimierza Alwesiaka, sercaniebelchatow.pl/historia-parafia-2/ (dostęp: 22.07.2017); R. Rydlak, Sercański Jubileusz w Betchatowie, w: Informator SCJ. Biuletyn Kurii Prowincjalnej Nr 1/2004, Warszawa 25 II 2004, s. 91-92.

${ }^{66}$ Por. R. Rybicki, Instytut świętego pedagoga, „Znak”, 12 (1960) s. 1299-1302. 
Biskup Józef Rozwadowski zwrócił się z prośbą do braci szkolnych o pomoc w prowadzeniu katechizacji na terenie diecezji łódzkiej. Dla zakonników była to bardzo dobra propozycja, ponieważ umożliwiała im przetrwanie trudnych czasów ${ }^{67}$. W latach 1981-1995 w Łodzi-Widzewie przy parafii pw. Matki Boskiej Jasnogórskiej katechizowało w pełnym wymiarze godzin od 4 do 6 braci tworzących wspólnotę zakonną. Podobnie też od 1983 roku trzech zakonników katechizowało w Ksawerowie-Pabianicach ${ }^{68}$. W 1987 roku bracia szkolni nabyli budynek w Piotrkowie Trybunalskim i podjęli katechizację w parafii pw. św. Jakuba, w Szkole Podstawowej nr 16, w Zespole Szkół Ponadpodstawowych, Liceum Ekonomicznym i Szkole Życia. Ponadto w tym domu otworzyli drugi nowicjat przed ślubami czasowymi. Od 1988 roku pięciu braci szkolnych tworzy wspólnotę zakonną w Piotrkowie Trybunalskim, gdzie prowadzą ośrodek formacyjny i katechetyczny oraz kaplicę ${ }^{69}$.

\section{Stowarzyszenie Apostolstwa Katolickiego (pallotyni)}

Łódź. Jako datę powstania pallotynów przyjmuje się rok 1846, kiedy to wspólnota z S. Salvatore in Onda założona przez św. Wincentego Pallottiego otrzymała kanoniczną aprobatę. Jej głównym zadaniem jest ożywianie apostolstwa świeckich w Kościele. Pierwszy dom pallotynów w Polsce powstał w 1907 roku w miejscowości Jajkowce (Antoniówka) na terenie parafii Kochawina w archidiecezji lwowskiej ${ }^{70}$.

Pallotyni w Łodzi przy ul. Łagiewnickiej nr $201 \mathrm{w}$ dzielnicy Bałuty posiadali prywatną działkę. W 1957 roku prowincjał pallotynów prosił biskupa łódzkiego o pozwolenie na erekcję domu, który zamierzali zbudować zakonnicy. Wymaganą zgodę otrzymali dopiero $\mathrm{w}$ roku $1985^{71}$. Właściwe prace zmierzające do powstania ośrodka duszpasterskiego rozpoczęli w 1989 roku od budowy kaplicy wewnątrz Domu Stowarzyszenia, którą 4 marca 1991 roku poświęcił biskup łódzki. Od 8 grudnia 1993 roku funkcjonowała już parafia pw. św. Wincentego Pallottiego. Metropolita łódzki abp W. Ziółek 17 września 2006 roku poświęcił plac pod budowę Sanktuarium Świętości Życia na tzw. łagiewnickim wzgórzu, a dekretem z 22 października 2011 roku ustanowił kościół św. Wincentego Pallotiego Sanktuarium Świętości Życia pw. Zwiastowania Pańskiego ${ }^{72}$.

${ }^{67}$ AAŁ, sygn. 42, t. Bracia Szkolni Łódź, Bp J. Rozwadowski do Zgromadzenia Braci Szkół Chrześcijańskich, Łódź 28 III 1981, L. dz., 447/81.

${ }^{68}$ AAt, sygn. 43, t. Bracia Szkolni, Pabianice, Otwarcie nowego domu zakonnego Braci Szkół Chrześcijańskich w Diecezji Łódzkiej, Łódź 26 X 1987; Instytuty życia konsekrowanego w Kościele łódzkim, red. K. Dąbrowski, L. Witczak, Łódź 2000, s. 15.

${ }^{69}$ AAŁ, sygn. 44, t. Bracia Szkolni, Piotrków Trybunalski, Kuria Biskupia Diecezji Łódzkiej do Kurii Prowincjalnej Zgromadzenia Braci Szkolnych w Częstochowie, Łódź 8 II 1988, L. dz., 203/88.

${ }^{70}$ Por. J. Dyl, Pallotyni w Polsce w latach 1907-1947, Lublin 2001, s. 68-69, 100-101.

${ }^{71}$ AAŁ, sygn. 78, t. Pallotyni, Ks. prowincja do bp. M. Klepacza, Warszawa 3 V 1957, bp J. Rozwadowski do ks. prowincjała Cz. Parzyszka, Łódź 28 X 1985.

${ }^{72}$ Dekret Arcybiskupa Łódzkiego erygujący parafię pw. Świętego Wincentego Pallottiego w Łodzi, „Wiadomości Archidiecezjalne Łódzkie”, 57 (1993) nr 12, s. 437-438, Dekret ustanawiają- 


\section{Zakon Braci Kaznodziejów (dominikanie)}

Łódź. W narożniku przy ul. Zielonej i Wólczańskiej dominikanie nabyli trzypiętrową kamienicę zbudowaną w 1910 roku, którą w latach 2004-2007 przebudowali na potrzeby wspólnoty zakonnej i prowadzenia działalności duszpasterskiej. Oficjalnie przebywają w niej od 28 listopada 2004 roku, a za patrona domu przyjęli bł. Piotra Jerzego Frassatiego. Pierwszy konwent składał się z trzech ojców i jednego brata zakonnego, a docelowo przewidziano lokale dla 10 zakonników. Dominikanie dobrze odczytali potrzeby mieszkańców i starają się odpowiedzieć na zapotrzebowania duchowe i społeczne wiernych. Pracę rozpoczęli od prowadzenia duszpasterstwa akademickiego i całodobowej posługi w konfesjonale ${ }^{73}$. Wprowadzili comiesięczne wykłady w ramach Dominikańskiej Szkoły Wiary. Na niedzielne Msze św. zapraszają rodziców z małymi dziećmi. Od czerwca 2009 roku propagują dwudniowe weekendowe (piątek-sobota) kursy dla narzeczonych. Dużą popularnością cieszą się bezpłatne warsztaty, tzw. Szkoła dla rodziców, którym trudno porozumieć się z własnymi dziećmi bądź mają z nimi kłopoty wychowawcze. W krótkim czasie dominikanie łódzcy rozwinęli wiele pomysłów duszpasterskich i ciągle występują z nowymi propozycjami ${ }^{74}$.

Swoje miejsce znaleźli w nowej diecezji łódzkiej misjonarze św. Wincentego à Paulo, bonifratrzy, karmelici bosi, filipini i dominikanie. Oprócz starych zakonów ordynariusze sprowadzali do pracy na teren diecezji także nowe, rozwijające się kleryckie zgromadzenia zakonne jak: salezjanie, oblaci Maryi Niepokalanej, pasjoniści, klaretyni, sercanie, pallotyni i polskie laickie zgromadzenia zakonne: albertyni oraz doloryści.

\section{Zakończenie}

Od początku powstania diecezji łódzkiej na jej terytorium życie zakonne rozwijało się dynamicznie i sukcesywnie w porównaniu z innymi Kościołami partykularnymi, nawet $\mathrm{z}$ tymi o starej metryce powstania. Zakony i zgromadzenia zakonne męskie aktywnie włączały się w życie Kościoła łódzkiego, organizowały nowe parafie, wznosiły świątynie, przejmowały i przystosowywały wolne obiekty sakralne po innych wyznaniach oraz na miarę możliwości realizowały charyzmat swojego powołania w Kościele. Księża i bracia zakonni dzielili los katolickiego społeczeństwa zarówno podczas okupacji niemieckiej, jak i w powojennym okresie rządów komunistycznych. Duszpasterze zakonni swoją działalnością obejmowali różne środowiska społeczne. W minionym, tzw. powojennym, okresie większe szanse przetrwania miały zakony i zgromadzenia zakonne kleryckie,

cy przy kościele św. Wincentego Pallottiego w Łodzi Sanktuarium świętości życia pod wezwaniem Zwiastowania Pańskiego, „Wiadomości Archidiecezjalne Łódzkie”, 85 (2011) nr 10, s. 753-754, Abp-453-1265/2011; A. Gracz, Sanktuarium świętości życia, „Nasz Dziennik”, 30 IV 2012.

${ }^{73} \mathrm{~W}$ roku 2015 pracowało 8 ojców i 2 braci. Por. Katalog Polskiej Prowincji Dominikanów 2015/2016, Warszawa 2015, s. 99-100; http:niedziela.pl/artykul/38380/nd/Dominikanie-w-Lodzi (dostęp: 21.07.2017).

${ }^{74}$ Łódź, Klasztor dominikanów, Dziedzictwo.ekai.pl/@lodz_dominikanie_klasztor (dostęp: 21.07.2017). 
które zaangażowały się w działalność duszpasterską poprzez prowadzenie parafii i kościołów rektoralnych. Godny odnotowania jest pozytywny fakt przejmowania przez zakony wolnych obiektów sakralnych innych wyznań i prawne unormowanie zagadnień własnościowych, np. jezuici przy ul. Sienkiewicza i karmelici bosi przy ul. Liściastej. Ponadto pierwsze kościoły w Łodzi w okresie Polski Ludowej udało się zbudować pasjonistom na Teofilowie i salezjanom w parafii św. Teresy od Dzieciątka Jezus. Księża zakonni przy swoich parafiach byli prekursorami duszpasterstwa specjalistycznego (jezuici, salezjanie) i nie pozwolili ograniczyć swojej działalności pasterskiej tylko do wnętrza świątyni, na czym tak bardzo zależało komunistom.

\section{BIBLIOGRAFIA}

\section{Źródła}

Archiwum Archidiecezji Łódzkiej

sygn. 31, t. Albertyni;

sygn. 39, t. Bonifratrzy Łódź;

sygn. 41, t. Bracia Serca Jezusowego Łódź;

sygn. 42, t. Bracia Szkolni Łódź;

sygn. 43, t. Bracia Szkolni Pabianice;

sygn. 44, 98, t. Bracia Szkolni Piotrków Trybunalski;

sygn. 45, 46, 47, 48, 49, 50, t. Doloryści;

sygn. 69,70 , t. Karmelici Bosi;

sygn. 75, t. Misjonarze Oblaci Grotniki;

sygn. 74, t. Misjonarze Oblaci Konstantynów;

sygn. 72, t. Misjonarze Pabianice;

sygn. 78, t. Pallotyni;

sygn. 70, t. OO. Pasjoniści;

sygn. 149, t. Parafia MB Bolesnej 1969-1981; t. Parafia św. Teresy w Łodzi.

Archiwum Państwowe w Łodzi

sygn. 1548, 1593, Wydział do Spraw Wyznań.

Archiwum Wyższych Przełożonych Zakonnych w Warszawie

akta bez sygn.

t. Albertyni;

t. Filipini-Oratorianie.

Archiwum Kurii Misjonarzy Klaretynów w Warszawie

akta bez sygn.

t. Łódź.

Archiwum Prowincjalne Zgromadzenia Sercanów w Warszawie, akta bez sygn.

Informator SCJ 25 VIII 1982 (mps).

Archiwum Salezjańskie Inspektorii Warszawskiej

akta bez sygn.

t. Lutomiersk;

t. Łódź św. Teresa; 
t. Łódź-Wodna;

t. Protokoły Posiedzeń Rad Inspektorialnych 1946-1950.

\section{Opracowania}

25-lecie klaretyńskiej Parafii Niepokalanego Serca NMP i św. Antoniego Klareta w Łodzi, Łódź 2014.

25-lecie działalności salezjańskiej w Polsce, Mikołów 1923.

Andrzejewski Łukasz, Dzieje Pasjonistów w Polsce w latach 1945-1990, Warszawa 2015 (mps).

Bar Joachim, Bracia Serca Jezusowego, w: Encyklopedia katolicka, t. 2, red. F. Gryglewicz, Lublin 1985, kol. 1006.

Duchniewski Jerzy, Doloryści, synowie MB Bolesnej, w: Encyklopedia katolicka, t. 4, red. R. Łukaszyk, Lublin 1985, kol. 46.

Dyl Janusz, Pallotyni w Polsce w latach 1907-1947, Lublin 2001.

Elenchus Polskiej Prowincji Zgromadzenia Księży Najświętszego Serca Jezusowego 2016, Kraków 2016.

Furczoń Józef, Początki Zgromadzenia Księży Sercanów w Polsce, w: Uwierzyliśmy miłości. 75 lat obecności Zgromadzenia Księży Sercanów w Polsce 1928-2003. Księga Jubileuszowa, red. G. Pisarek, Kraków 2004, s. 31-44.

Gapski Henryk, Bonifratrzy w Europie Środkowo-Wschodniej do końca XVIII wieku. Rozwój sieci konwentów i szpitali, w: Bracia, czyńcie dobro. 400 lat Zakonu Bonifratrów w Polsce 1609-2009, red. Marian Surdacki, Kraków 2009, s. 51-60.

Gil Czesław, Karmelici Bosi, w: Encyklopedia katolicka, t. 8, red. B. Migut, Lublin 2000, kol. 814-819.

Instytuty życia konsekrowanego w Kościele łódzkim, red. K. Dąbrowski, L. Witczak, Łódź 2000.

Janaczek Stanisław, Powstanie i organizacja Krakowskiej Prowincji Księży Misjonarzy (1865-1914), „Nasza Przeszłość”, 86 (1996) s. 361-432.

Jaromir Henryk, Zarys historii Kongregacji Oratorium świętego Filipa Neri w Polsce 1668-1968, „Nasze Przeszłość”, 32 (1970) s. 5-145.

Katalog Polskiej Prowincji Dominikanów 2015/2016, Warszawa 2015.

Krzemiński Jan, Lutomiersk na przestrzeni dziejów, Lutomiersk 1974.

Kwietniewski Marek, Parafia Matki Bożej Wspomożenia Wiernych w Łodzi do roku 1991, Łódź-Lublin 2002 (mps).

Łoziński Bogumił, Leksykon zakonów w Polsce. Informator o życiu konsekrowanym, Warszawa 1998.

Łukaszewski Stanisław, Na pamiątkę konsekracji dzwonów kościelnych Parafii św. Teresy $w$ Łodzi, Łódź 1931.

Łań-Mirowska Henryka, Bonifratrzy w Polsce (1609-1983), Rzym 1984.

Łobozek Marcin Maksymilian, Bonifratrzy w Lodzi 1925-1995, Łódź 1995.

Markowski Bogdan, Kościół i Parafia Najświętszej Maryi Panny w Pabianicach 18981998, Pabianice 1998.

Mazurek Maria, Wójcik Maria, Honorackie zgromadzenia bezhabitowe $w$ latach 18741914 w Królestwie Polskim i Cesarstwie Rosyjskim na ziemiach polskich w XIX i na początku XX wieku, red. H. Dylągowa, Lublin 1976, s. 201-390.

Misjonarz Klaretyni 1807-2007 śladami ojca Klareta. Zarys historii Zgromadzenia Misjonarzy Klaretynów C. M. E., red. K. Gierat, Warszawa 2007.

Nowacki Józef, Dzieje Archidiecezji Poznańskiej, t. 2: Archidiecezja poznańska w granicach historycznych i jej ustrój, Poznań 1964. 
Pietrzykowski Jan, Salezjanie w Lutomiersku wczoraj a dziś, „Seminare. Poszukiwania Naukowo-Pastoralne", 12 (1996) s. 291-310.

Pietrzykowski Jan, Salezjanie w Polsce 1945-1989, Warszawa 2007.

Pietrzykowski Jan, Szkoła salezjańska w Łodzi 1922-1992, „Seminare. Poszukiwania Naukowo-Pastoralne", 10 (1994) s. 229-243.

Pietrzykowski Jan, Wkład salezjanów w życie Kościoła (Archi)diecezji Łódzkiej 19221998, „Łódzkie Studia Teologiczne”, 7 (1998) s. 307-317.

Pietrzykowski Jan, Zakony i zgromadzenia zakonne męskie na ziemiach polskich na przetomie XIX i XX wieku. Z uwzględnieniem diecezji janowskiej czyli podlaskiej, „Roczniki Historii Polski", 4 (59) (2012) s. 85-100.

Prejs Roland, Zakonnicy franciszkańscy w Królestwie Polskim po kasacie 1864 roku. Dzieje-postawy, Warszawa 2003.

Rosin Ryszard, Studia z dziejów miast dawnych województwa łęczyckiego i sieradzkiego (XII-XVI w.), Łódź 1959.

Salwa Tadeusz, Litewska Prowincja Księży Misjonarzy (1794-1842), „Nasza Przeszłość”, 56 (1981) s. 147-235.

Schematyzm diecezji kujawsko-kaliskiej 1920, Włocławek 1920.

Szczerba Kazimierz, Kontakty Polaków z księdzem Janem Bosko, „Seminare. Poszukiwania Naukowo-Pastoralne", 9 (1987-1988) s. 111-137.

Strzeszewski Czesław, Kościół katolicki w Polsce wobec zagadnień społeczno-gospodarczych (966-1918), w: Księga Tysiąclecia Katolicyzmu w Polsce, t. 3, red. M. Rechowicz, Lublin 1969, s. 261-430.

Szpakowski Roman, Zgromadzenie Braci Serca Jezusowego w Polsce $w$ latach 19231983, Warszawa 1986.

Umiński Wacław, Polska Prowincja Zgromadzenia Księży Misjonarzy w latach 19181939, Kraków 2009.

Wanat Benignus Józef, Zakon Karmelitów Bosych w Polsce. Klasztory karmelitów i karmelitanek bosych 1605-1975, Kraków 1979.

Wiśniowski Grzegorz, Franciszkanie reformaci w latach 1772-1970, w: Zakony św. Franciszka w Polsce w latach 1772-1970, red. J. Bar, cz. 3, Warszawa 1978, s. 133-183.

Wojtyska Henryk Damian, Historia Zgromadzenia Pasjonistów w Polsce, t. 1, Łódź 2006.

Wróbel Robert, Nowe kościoły w diecezji łódzkiej 1945-1989, Łódź 2005.

Zając Paweł, Fundacje klasztorne Misjonarzy Oblatów Maryi Niepokalanej w Archidiecezji Poznańskiej w latach 1922-1939, „Ecclesia. Studia z Dziejów Wielkopolski”, 5 (2010) s. 147-172.

Ziemann Eugeniusz, Sercanie, Zgromadzenie Księży Najświętszego Serca Jezusowego, w: Encyklopedia katolicka, t. 18, red. E. Gigilewicz, Lublin2013, kol. 3-4.

Zimniak Stanisław, Salesiani nella Mitteleuropa Preistoria e storia della provincia Austro-Ungarica della Societá di S. Francesco di Sales (1868 ca-1919), Roma 1997.

Zwoliński Piotr, Działalność społeczno-dobroczynna Kościoła lódzkiego w okresie międzywojennym (studium historyczne), Łódź 2006.

Żurek Waldemar, Salezjańskie szkolnictwo ponadpodstawowe w Polsce 1900-1963. Ustrój i organizacja, Lublin 1996. 


\title{
MALE ORDERS AND MONASTIC CONGREGATIONS AP- PEARING IN THE (ARCH)DIOCESE OF LÓDŹ IN PRESENT TIMES
}

\begin{abstract}
Summary
In the territory of the diocese of Łódź, which was established in 1920, both newly and previously formed monastic congregations undertook their activities. There were also some unprecedented appearances like those of third orders existing temporarily (Dolorist Brothers, Albertine Brothers, Sacred Heart Brothers) and permanently (Brothers of Mercy, Christian Brothers). As far as the traditional "first" orders and monastic congregations existing in the Old Polish period, the first ones that appeared in the 20th century in the diocese of Łódź were Vincentians who came to Pabianice in 1919. In turn, after the Second World War Carmelites of the Ancient Observance and Oratorians settled in Łódź and Tomaszów Mazowiecki respectively. What is more, during the interwar period 3 centres were founded by Salesians: a didactic centre in Łódź, a priesthood centre in Łódź and a care centre in Lutomiersk. The remaining monastic congregations are in charge of one parish both in Łódź and in the territory of the archdiocese: Oblates (Grotniki), Passionists, Claretians, Dehonians (Bełchatów) and Pallottines. Dominicans arrived as the last ones, moving into a 3-storey tenement house in Łódź in 2004. Monks conduct their activities in various social environments and attempt to fulfil their mission in the local Church.
\end{abstract}

Keywords: the archdiocese of Łódź; monastic congregations; priesthood; didactic activities 